\title{
Beberapa Problematik Ekonomi Indonesia Memasuki Abad XXI
}

\author{
Edy Suandi Hamid
}

\section{LuberalisasI Ekonoml}

alah satu hasil dari pertemuan pemimpin ekonomi APEC dalam forum APEC Economic Leaders Meeting (AELM) yang ke-4 di Manila tanggal 25 November 1996 yang lalu adalah menyangkut kesepakatan untuk memulai liberalisasi perdagangan dan investasi di kawasan Asia Pasifik. Keputusan ini sebenarnya bukan sesuatu yang sangat mengejutkan mengingat visi dan rencana aksi ke arah itu memang sudah dikemukakan sejak AELM ke-2 di Bogor (1994) dan AELM ke3 di Osaka-Jepang (1995). Di samping itu, makna liberalisasi yang dikemukakan tersebut juga tidak daiam artian liberalisasi yang menyeluruh, melainkan dalam konteks permulaan untuk mewujudkan suatu liberalisasi yang lebih luas dan lebih menyeluruh, sehingga pada tahun 2010 bagi negara-negara maju, dan 2020 bagi negara-negara berkembang, tidak ada lagi hambatan yang berari dalam perdagangan dan investasinya. Dengan demikian, pada tahun-tahun tersebut hubungan ekonomi antarnegara menjadi lebih bebas, dan tidak terlalu dibatasi oleh ketentuan-ketentuan spesifik atau diskriminatif untuk terjadinya hubungan ekonomi antar-negara ataupun antarwarga negara.

Dilihat dari sisi perdagangan, maka Indonesia sebenarnya juga sudah banyak meliberalkan komoditi tertentu untuk ke luar-atau masuk Indonesia dengan tanpa dikenakan tarif ekspor maupun bea masuk, dan tanpa dikenai hambatan berupa bukan-tarif (non-tariff barriers) seperti larangan impor, kuota impor, tata niaga dan sebagainya. Atau, untuk komoditi yang diimpor, kalaupun dikenakan bea masuk, tarifnya sangat rendah, yakni lebih kecil dari lima persen. Setelah deregulasi tanggal 4 Juni 1996, dari 7.288 pos tarif impor yang ada, sebanyak 3.465 pos tarif atau 47,54 , tingkat bea masuknya hanya berkisar $0-5 \%$. Sementara untuk tarif yang kategorinya tinggi, yakni $25-35 \%$ dan minimal $40 \%$ masing-masing masih melingkupi $1.472(20,2 \%)$ dan $95(1,30 \%)$ pos tarif yang ada. Namun demikian, walaupun sudah banyak komoditi yang diliberalkan perdagangannya, namun di antara negara-negara anggota APEC, tingkat tarif nominal rata-rata yang ditetapkan Indonesia memang masih relatif tinggi (Tabel 1). 
Tabel 1: Tarif Rata-rata Sederhana Anggota APEC 1988-1996 (\%)

\begin{tabular}{|c|c|c|c|}
\hline \multirow[t]{2}{*}{ Anggota } & \multicolumn{3}{|c|}{ Aprkas Tari Berdasarikan Ratarata Sederhana } \\
\hline & 19883 & 19996 & 1996 \\
\hline Austata' & 15,60 & 7.00 & 5,00 \\
\hline Bunai & 3,90 & 3,90 & 1,98 \\
\hline Karada" & 3,70 & 2.40 & $1,60 \mathrm{c}$ \\
\hline & 19,90 & 11,00 & $\$ 1,00$ \\
\hline Cina & 39,90 & 37,50 & 200 \\
\hline Hongkong & 0,00 & 0,00 & 0,00 \\
\hline Indonesia & 18,10 & 17,00 & 13,14 \\
\hline Jepeng" & 4,30 & 3,40 & 4,00 \\
\hline Korea Salatan & 19,20 & 11,60 & 7,90 \\
\hline Malaysia & 13,60 & 12,80 & 9,00 \\
\hline Meks'so" & 10,50 & 12,60 & 9,80 \\
\hline Selandia Bay & 14,90 & 8,50 & 5,70 \\
\hline Papua Kugini & & . & 23,00 \\
\hline Filpina & 27,90 & 23,50 & 15,57 \\
\hline Singapera & 0,30 & 0,40 & $0,00 \mathrm{~d}$ \\
\hline Taiwan & 12,57 & 8.89 & 8.64 \\
\hline Thatand & 3120 & 37,80 & 17,000 \\
\hline$A S$ & 4,20 & 4,20 & 3,40 \\
\hline
\end{tabular}

Keterangan :

a). 1984 - 1987 untuk negara berkembang

b). 1991 - 1993 untuk negara berkembang

c). didasarkan pada tahun 1995

d). kalkulasinya tak mengikutkan tarif tertentu untuk sektor pertanian

e). rata-rata tarif tahun 1997

-) data berdasarkan rata-rata tertimbang

Sumber : Brunei, Kanada dan Cile tahun 1993, Filipina 1984 -1987, Taiwan 1991 - 1993. Lainnya diambil dari bahan PECC (Pacific Economic Cooperation Council), 1995, Survey of Impediments to Trade and Investment in the APEC Region, data didasarkan pada UNCTAD. Data tahun 1996 diambil dari agenda aksi individu yang dibawa ke Manila (Kompas, 26 Nopember 1996).

Pada tabel di atas tergambar bahwa tingkat tarif rata-rata Indonesia saat ini mencapai $13,14 \%$ atau peringkat ke-empat tertinggi dari 18 anggota APEC, di bawah Cina, Papua Nugini dan Thailand. Namun demikian sebenarnya tarif efektif yang ditetapkan Indonesia tersebut, jika dilihat dari Effective Rate of Protection, jauh dari angka di atas. Ini mengingat Indonesia masih menerapkan beberapa hambatan non-tarif yang membuat sulitnya arus barang dari negara lain masuk ke Indonesia. Lebih dari itu, untuk sebagian komoditi yang tarifnta relatif tinggi, ternyata merupakan komoditi yang potensi nilai perdagangan internasionalnya tinggi, seperti yang tercermin pada produk otomotif atau sebagian komoditi pertanian.
Tingginya tingkat proteksi, baik melalui tarif dan bukan tarif, yang dilakukan Indonesia memang tidak terlepas dari sejarah ekonomi kita yang sejak zaman kolonial sudah melakukan proteksi untuk melindungi pasar dan produsen dalam negeri. Dengan sikap Indonesia yang telah menyetujui untuk mengintegrasikan ekonominya melalui AFTA (ASEAN Free Trade Area), APEC dan WTO (World Trade Organisation), maka berbagai bentuk proteksi tersebut harus dihilangkan. Misalnya saja, dalam kaitannya dengan AFTA, Indonesia sudah hans meliberalkan perdagangan 15 kelompok komoditinya pada tahun 2003. Sementara itu, liberalisasi yang lebih luas di Asia Pasifik juga sudah hanus dilaksanakan pada tahun 2020. Dalam konteks APEC dan WTO, liberalisasi tidak hanya sebatas perdagangangan barang saja, melainkan juga meliputi perdagangan jasa, investasi dan sebagainya. Jadi banyak penyesuaian kebijakan yang harus dilakukan indonesia dalam memasuki abad XXI ini.

\section{Kinerja Ekonomi Indonesia}

Dengan melihat kinerja ekonomi Indonesia belakangan ini, maka muncul pertanyaan tentang sejauh mana kesiapan indonesia untuk masuk dalam era liberalisasi tersebut. Baik dibandingkan dengan anggota AFTA maupun anggota APEC, kondisi ekonomi Indonesia di ASEAN memang masih relatif tertinggal. Dengan menggunakan indikator pendapatan per kapita, maka tingkat pendapatan per kapita Indonesia termasuk yang berada di lapisan bawah, dan hanya sedikit lebih tinggi dibanding Filipina, di samping Vietnam. Begitu pula tingkat industrialisasinya masih jauh ketinggalan dibandingkan Malaysia, Singapura, dan Thailand. Sementara itu, persaingan di APEC jauh lebih ketat lagi. Jika dalam AFTA, tidak ada negara maju di dalamnya, maka di APEC terdapat dua negara yang "sudah sangat maju" (Amerika Serikat dan Jepang), serta negara "maju" (Kanada, 
Australia, Selandia Baru dan Hongkong), di samping tiga "negara industri baru/NICs" (Korea Selatan, Singapura dan Taiwan). Sementara di antara negara-negara berkembang di APEC, juga ada negara yang saat ini secara raltif ekonomi lebih tangguh dibanding Indonesia, yakni Malaysia, Thailand, Meksiko, maupun Chile.

Adanya sejarah proteksi yang panjang dalam ekonomi nasional Indonesia merupakan salah satu faktor utama yang menyebabkan lemahnya dayasaing tersebut. Untuk meningkatkan dayasaing ini tampaknya bukan suatu persoalan yang gampang. Budaya proteksi yang cukup mengakar dalam ekonomi nasional, menuntut waktu yang relatiff panjang untuk menghilangkannya. Yang lebih menyulitkan lagi adalah pada saat Indonesia berupaya keras meningkatkan dayasaing ini, melalui berbagai deregulasi yang diadakan, negara lain pun melakukan hal yang tidak kalah seriusnya. Dengan kondisi itu, tidak mengherankan kalau dayasaing Indonesia ini sulit beranjak, bahkan mengalami kemerosotan. Data dari World Competitiveness Report (1996) menunjukkan bahwa peringkat daya saing Indonesia dibandingkan negara Asia lainnya, menunun dari peringkat ke 33 pada tahun 1995 menjadi peringkat ke-41 dari 46 negara (Tabel 2).

Tabel 2: Peringkat Daya Saing Negara-negara Asia

\begin{tabular}{cccccccc}
\hline Negara & $\begin{array}{c}\text { Peringkat } \\
\text { keselunutan }\end{array}$ & $\begin{array}{c}\text { Kekuatan } \\
\text { akonomi } \\
\text { domestik }\end{array}$ & $\begin{array}{c}\text { Kemampuan } \\
\text { menembus pasa } \\
\text { Intemasional }\end{array}$ & $\begin{array}{c}\text { Suriberdaya } \\
\text { manusia }\end{array}$ \\
1995 & 1996 & 1996 & 1996 & 1996 & 1996 & 1995 & 1996 \\
\hline
\end{tabular}

\begin{tabular}{|c|c|c|c|c|c|c|c|c|}
\hline 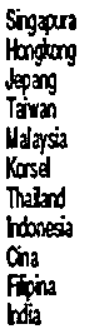 & $\begin{array}{l}2 \\
3 \\
4 \\
11 \\
21 \\
24 \\
26 \\
39 \\
34 \\
35 \\
39\end{array}$ & $\begin{array}{l}2 \\
3 \\
4 \\
18 \\
23 \\
27 \\
30 \\
41 \\
26 \\
31 \\
36\end{array}$ & $\begin{array}{l}2 \\
3 \\
4 \\
7 \\
5 \\
6 \\
9 \\
7 \\
12 \\
33 \\
28\end{array}$ & $\begin{array}{c}3 \\
8 \\
5 \\
11 \\
7 \\
1 \\
12 \\
25 \\
2 \\
29 \\
32\end{array}$ & $\begin{array}{l}1 \\
3 \\
9 \\
11 \\
21 \\
34 \\
22 \\
32 \\
21 \\
20 \\
40\end{array}$ & $\begin{array}{l}1 \\
4 \\
14 \\
26 \\
16 \\
43 \\
33 \\
37 \\
23 \\
31 \\
41\end{array}$ & $\begin{array}{c}1 \\
19 \\
6 \\
16 \\
25 \\
21 \\
26 \\
4 \\
40 \\
40 \\
7\end{array}$ & $\begin{array}{l}8 \\
22 \\
4 \\
16 \\
34 \\
21 \\
40 \\
45 \\
35 \\
35 \\
4\end{array}$ \\
\hline
\end{tabular}

Surner: Wadt Competiveness Repor, 1996 Irilh negara yang ósurvi is negara.
Kalau pada tahun 1995, peringkat dayasaing Indonesia - yang diukur dari 225 kriteria - masih di atas Filipina, India dan China, maka tahun 1996 ketiga negara tersebut sudah lebih tinggi dayasaingnya dibanding Indonesia.

Tabel di atas juga menggambarkan bagaimana posisi sumberdaya manusia Indonesia dari 46 negara yang disurvei oleh WCR. Dilihat dari indikator SDM tersebut, Indonesia menempati peringkat ke 45 , yang mencerminkan rendahnya kualitas SDM kita. Walaupun hasil survei WCR ini masih bisa dipertanyakan, namun dengan rendahnya tingka dayasaing Indonesia versi WCR tersebut paling tidak mengingatkan bahwa ada persoalan yang sangat besar bagi ekonomi Indonesia menghadapi era liberalisasi ekonomi yang secara lebih cepat akan dimasuki mulai abad ke-21 yang tinggal tiga tahun lagi.

Tabel 2 tersebut mengisyaratkan besamya problematik Indonesia untuk bersaing dengan negara-negara yang secara teoritik kini sudah di atas Indonesia. terutama negara-negara industri dan negara industri baru, yang sejarah persaingan atau liberalisasi ekonominya memang sudah jauh lebih dulu dimulai dibandingkan Indonesia.

Melihat kenyataan yang demikian, maka mau atau tidak mau, Indonesia perlu melakukan akselerasi di berbagai bidang dan kebijakannya, supaya dapat secara lebih cepat meningkatkan dayasaing tersebut. Upaya tersebut sudah harus dilakukan dalam jangka pendek ini mengingat era liberalisasi ekonomi sudah semakin dekat. Berbagai deregulasi, melalui upaya pengurangan dan penghapusan proteksi, debirokratisasi, penetapan kebijakan yang nondiskriminatif, yang dimaksudkan untuk menghilangkan ekonomi biaya tinggi (high cost economy) atau mengurangi inefisiensi, sudah mendesak untuk diwujudkan. Berbagai pertimbangan non-ekonomi, ataupun yang terkait dengan vested interest tertentu, sudah tidak sewajarnya lagi 
untuk dimasukkan sebagai variabel dalam penetapan kebijakan ekonomi nasional. Dengan kata lain, kebijakan-kebijakan yang ada benar-benar di arahkan pada perbaikan kinerja ekonomi dalam menyongsong liberalisasi ekonomi di masa yang akan datang.

Sejauh ini masih sering terlihat adanya kebijakan-kebijakan ekonomi yang bias pada kepentingan pelaku ekonomi tertentu, dan tidak sejalan dengan kepentingan ekonomi nasional. Teralokasinya proyek-proyek besar pemerintah pada pengusaha tertentu yang tidak melalui fair tender, bisnis pihak-pihak tertentu yang dekat dengan pengambil keputusan sehingga memperoleh keistimewaan, merupakan sinyalemen yang menjadi rahasia umum di tanah air. Jika praktek demikian benar-benar terjadi, maka dapat diduga bahwa dampaknya sangat merugikan bagi kepentingan ekonomi secara makro. Keputusan atau kebijakan yang bias tersebut, atau tidak melalui mekanisme pasar yang benar, akan cenderung menimbulkan ketidakefisienan. Suatu unit usaha, misalnya, yang mendapat fasilitas proteksi, bila ini berkepanjangan, akan berdampak pada lemahnya daya saing unit usaha tersebut. Padahal dalam jangka panjang, fasilitas tersebut nantinya tidak akan bisa diperoleh lagi. Dengan demikian pada waktu proteksi harus dicabut, dan unit usaha yang diproteksi belum siap bersaing, maka unit usaha tersebut akan terancam bangkrut. Namun memang bagi unit usaha tersebut tidak terlau dirugikan, karena keuntungan pada masa menikmati proteksi sudah sangat besar. Tetapi akibatnya bagi ekonomi nasional akan sangat merugikan. Sebab pada saat proteksi dicabut, bisa jadi pengusaha nasional lain belum ada yang siap, karena sebelumnya memang tidak mempunyai peluang untuk berkembang. Akibatnya, yang akan menggantikannya adalah unit usaha dari negara lain, yang pada era AFTA ataupun APEC nantinya sudah bisa lebih leluasa memasuki pasar Indonesia.

Dilihat dari aspek pertumbuhan ekonominya, sejak tiga dasawarsa terakhir ini sebenamya pertumbuhan ekonomi indonesia cukup meyakinkan. Bahkan oleh Bank Dunia, Indonesia termasuk satu dari sedikit negara di Asia Timur yang dianggap sebagai "ajaib" pertumbuhan ekonominya. Sebagai gambaran, misalnya, dalam tiga tahun terakhir ini perekonomian indonesia, dilihat dari laju PDB riilnya, tumbuh dengan $7,5 \%-8,1 \%$ per tahun. Angka ini lebih tinggi dibandingkan kebanyakan negara lainnya. Sementara pengendalian harga, juga relatif berhasil, walaupun masih pada tingkat yang moderat dan belum pada level inflasi yang rendah (lihat Tabel 3).

Untuk dapat mempertahankan pertumbuhan ekonomi yang tinggi tersebut, menuntut adanya suatu investasi yang besar púla. Namun investasi yang besar saja juga tidak akan banyak manfaatnya kalau pasar dari produk yang dihasilkan oleh investasi itu terbatas. Karenanya untuk dapat mempertahankan pertumbuhan ekonomi ini, diperlukan iklim yang lebih kondusif bagi para pemilik dana, baik domestik (PMDN) maupun asing (PMA). Untuk menarik PMA, saat ini bukan pekerjaan yang gampang. Berbagai negara berupaya menarik modal asing ke negerinya dengan memberikan insentifinsentif menarik, dan birokrasi yang sederhana. Data dari Bank Dunia (1996) menunjukkan bahwa pada tahun 1994, Indonesia hanya mampu memperoleh $2,63 \%$ saja dari total investasi asing yang masuk ke negara berkembang. Sementara Cina menyerap $42,17 \%$, dan negara tetangga kita Malaysia memperoleh $5,43 \%$. Kompetisi untuk menarik PMA ini akan lebih gencar lagi pada tahun-tahun yang akan datang, sejalan dengan era liberalisasi tersebut. Orang tidak harus membuat industri di Indonesia, walaupun target pasar terbesarnya adalah Indonesia. Faktor fasilitas, birokrasi, SDM, dan sebagainya akan menjadi pertimbangan pula bagi investor asing (atau bahkan juga 
Tabel 3: Pertumbuhan PDB Riil dan Inflasi di Negara Berkembang 1994-1996

\begin{tabular}{|c|c|c|c|c|c|c|}
\hline & \multicolumn{3}{|c|}{ PDB } & \multicolumn{2}{|c|}{ INFLASI } & \multirow[b]{2}{*}{1996} \\
\hline & 1994 & 1995 & 1996 & 1994 & 1995 & \\
\hline $\begin{array}{l}\text { Negara Berkembang } \\
\text { Medan } \\
\text { Afrika } \\
\text { Maroko } \\
\text { Tunisia } \\
\text { Uganda } \\
\text { Asian } \\
\text { China } \\
\text { Hongkong }\end{array}$ & $\begin{aligned} 6,4 \\
3,6 \\
2,4 \\
2,4 \\
11,5 \\
3,4 \\
30,0 \\
10,0 \\
8,8 \\
11,8 \\
5,4\end{aligned}$ & $\begin{array}{r}5,9 \\
4,1 \\
3,2 \\
-6,0 \\
3,5 \\
6,5 \\
8,4 \\
10,2 \\
5,0\end{array}$ & $\begin{array}{r}6,3 \\
4,5 \\
5,3 \\
9,1 \\
6,7 \\
6,0 \\
8,2 \\
10,0 \\
5,0\end{array}$ & $\begin{array}{r}48,0 \\
11,3 \\
33,8 \\
5,1 \\
4,7 \\
6,1 \\
6,1 \\
13,5 \\
21,7 \\
8,1\end{array}$ & $\begin{array}{r}19,9 \\
8,9 \\
25,8 \\
6,6 \\
6,2 \\
5,0 \\
10,9 \\
14,8 \\
9,0\end{array}$ & $\begin{array}{r}12,6 \\
6,0 \\
13,7 \\
5,0 \\
5,0 \\
6,0 \\
8,4 \\
10,0 \\
7,5\end{array}$ \\
\hline Indonesia & 7.5 & $-8,1$ & 7,6 & $\overline{\mathbf{B}, 5}$ & 9,4 & 9,1 \\
\hline $\begin{array}{l}\text { Korea } \\
\text { Malaysia } \\
\text { Filipina } \\
\text { Singapura } \\
\text { Taiwan } \\
\text { Thailand } \\
\text { Vietnam }\end{array}$ & $\begin{array}{r}8.4 \\
9,2 \\
4,4 \\
10,1 \\
6,4 \\
8,9 \\
8,9\end{array}$ & $\begin{array}{l}9,0 \\
9,6 \\
4,8 \\
8,9 \\
6,4 \\
9,5 \\
9,5\end{array}$ & $\begin{array}{l}7.5 \\
9,0 \\
6,1 \\
7,5 \\
6,2 \\
9,5 \\
9,5\end{array}$ & \begin{tabular}{r|}
8,5 \\
3,7 \\
9,1 \\
3,1 \\
4,1 \\
14,5 \\
14,5
\end{tabular} & $\begin{array}{r}9.4 \\
3,4 \\
8,1 \\
1,7 \\
3,7 \\
13,1 \\
13,1\end{array}$ & $\begin{array}{l}9,1 \\
4,2 \\
8,0 \\
1,7 \\
3,7 \\
9,0 \\
9,0\end{array}$ \\
\hline Timur Tengah dan Eropa & 0,7 & 3,7 & 3.1 & 32,0 & 33,1 & 23.8 \\
\hline $\begin{array}{l}\text { Israel } \\
\text { Yordania } \\
\text { Belahan Barat } \\
\text { Chili } \\
\text { Republik Dominika }\end{array}$ & $\begin{array}{l}6,5 \\
5,9 \\
4,7 \\
4,2 \\
4,3\end{array}$ & $\begin{array}{l}6,9 \\
6,4 \\
0,9 \\
8,5 \\
4,8\end{array}$ & $\begin{array}{l}5,7 \\
6,5 \\
3,1 \\
6,5 \\
5,0\end{array}$ & $\begin{array}{r}12,3 \\
3,5 \\
22,3 \\
1,4 \\
8,3\end{array}$ & $\begin{array}{r}10.0 \\
3.0 \\
37.9 \\
8.2 \\
12,5\end{array}$ & $\begin{array}{r}9,0 \\
3,5 \\
19,0 \\
7,4 \\
7.1\end{array}$ \\
\hline
\end{tabular}

Sumber : IMF, World Economic Outlok, Washington DC, Mei 1996

domestik) untuk melakukan investasi di Indonesia.

\section{Masalah Sumberdaya Manusia}

Jika dilihat secara teoritik, maka adanya suatu liberalisasi ekonomi dapat menguntungkan bagi semua negara yang terlibat di dalamnya. Liberalisasi ekonomi mengandung makna menurunnya berbagai bentuk proteksi yang ada dalam hubungan ekonomi antarnegara, atau dalam suatu negara. Menurunnya proteksi akan meningkatkan terjadinya kompetisi antarpelaku ekonomi yang ada. Sebagai akibat dari kompetisi atau persaingan tersebut, para pelaku ekonomi akan mencari polapola produksi yang paling efisien dengan maksud agar produk (barang/jasa) yang dihasilkan bisa diterima konsumen. Polapola produksi yang selanjutnya terjadi adalah didasarkan pada alokasi sumberdaya yang terbaik atau paling efisien. Jika ini terjadi, maka output pun (baik di tingkat domestik ataupun dunia) akan bertambah, yang berarti bertambah pula kemakmuran masyarakat suatu negara atau dunia.

Bagi negara-negara seperti Indonesia, yang tingkat keterbukaan ekonominya sangat tinggi (dilihat dari rasio perdagangan internasional terhadap PDB), maka adanya liberalisasi ekonomi akan memberi peluang lebih besar untuk memasuki pasar internasional tanpa khawatir dihambat oleh berbagai proteksi. Arus modal ke Indonesia juga diharapkan bisa meningkat lebih besar guna mengatasi kekurangan kapital yang dihadapi oleh ekonomi Indonesia sejak dulu sampai sekarang. Masuknya kapital atau modal asing lebih banyak tersebut dimungkinkan karena pemilik modal yang melakukan investasi di Indonesia, tidak lagi khawatir akan keterbatasan pasar. Walaupun industri atau pabrik yang dibangunnya 
berada di Indonesia, mereka dapat menjual hasilnya ke negara lain tanpa hambatan berarti. Jadi, dengan liberalisasi ekonomi skala ekonomi dari investasi yang besar tidak lagi menupakan problematik sebagai akibat luasnya pasar. Sebagai misal, adanya AFTA telah membuat pabrik mobil Honda mau membangun industri di Thailand. Sebelumnya hal tersebut tidak terjadi, karena untuk dapat efisien industri mobil di suatu negara harus mampu memasarkan ratusan ribu unit setiap tahunnya, dan ini sulit terjadi jika pasarnya hanya dalam satu negara.

Namun demikian berbagai manfaat yang mungkin diperoleh tersebut dapat mewujud jika antisipasi dilakukan oleh Indonesia, baik dengan berbagai kebijakan yang kondusif untuk mendukung peningkatan efisiensi ini, maupun melalui peningkatan kualitas SDM yang saat ini masih sangat tertinggal. Kebijakan yang diambil juga perlu konsisten, dan tidak paradoksal dengan kecenderungan ekonomi dunia yang semakin mengarah pada persaingan bebas tersebut. Kebijakan. mobil nasional, misalnya, merupakan kasus yang memberikan kesan sangat paradoks dengan semangat liberalisasi ekonomi, yang menolak adanya suatu diksriminasi.

Dalam konteks persoalan SDM di Indonesia; memang sangat kompleks. Padahal SDM ini sangat menentukan keberhasilan dalam era globalisasi atau liberalisasi tersebut. Masalahnya tidak saja pada jumlah yang besar dengan tingkat pertumbuhan relatif tinggi, melainkan juga berkaitan dengan tingkat pendidikan dan kualitas yang rendah, sehingga kemampuan berproduksinya (produktivitasnya) juga sangat rendah. Saat ini sekitar $70 \%$ dari angkatan kerja Indonesia hanya berpendidikan Sekolah Dasar atau lebih rendah. Sebagai gambaran tentang problematik SDM Indonesia inj dapat dilihat pada Tabel 4
Tabel 4: Potensi dan Problem Angkatan Kerja Indonesia

\begin{tabular}{|c|c|c|c|c|}
\hline & 1993 & 1994 & 2000 & 2010 \\
\hline Angkatan kerja (juta orang) & 70,25 & 83,70 & 97,36 & 125,71 \\
\hline Kesempatan Keria (jta ofang) & 69,39 & 72,54 & 89,36 & 117,14 \\
\hline \multicolumn{5}{|l|}{ Pengangguran } \\
\hline \multicolumn{5}{|l|}{ 1. Penganggur $<1 \mathrm{jam}$} \\
\hline Absolut (juta orang) & 2,20 & 3,65 & 1,30 & 1,63 \\
\hline (persen) & 2,78 & 4,37 & 1,33 & 1,30 \\
\hline \multicolumn{5}{|l|}{ 2. Penganggur <15 jam } \\
\hline Absolut (juta orang) & 9,86 & 11,15 & 8,02 & 8.57 \\
\hline (persen) & 11,81 & 13,33 & 8,24 & 6,82 \\
\hline \multicolumn{5}{|l|}{ 3. Penganggur $<35 \mathrm{jam}$} \\
\hline Absolut (juta orang) & 32,7 & 33,35 & 30,84 & 37,02 \\
\hline (persen) & 41,26 & 39,85 & 31,67 & 29,45 \\
\hline
\end{tabular}

Catatan : -

Tahun 1993 dan 1994 data dari Sakernas 1993, 1994

Tahun 2000 dan 2010 menpakan angka perkiraan Depraker

Sumbor : Pusat Informasi Kompas

Satu masalah ketenagakerjaan yang sudah lama muncul dalam ekonomi Indo: nesia adalah berkaitan dengan problematik pengangguran. Dengan berbagai definisi, kita melihat bahwa tingkat pengangguran tersebut sudah sangat tinggi. Jika pengertian "menganggur" adalah mereka yang bekerja kurang dari satu jam per minggu, maka tingkat pengangguran di lndonesia hanya $2,78 \%(1994)$, dan diproyeksikan tinggal $1,3 \%$ pada tahun 2010. Namun tentu sangat tidak realistik untuk menggunakan definisi ini untuk menunjukkan jumlah pengangguran sebenarnya di tanah air. Karena adalah sangat muskil untuk kebanyakan orang dapat menghidupi diri dan anggota keluarganya jika hanya bekerja satu jam per minggu.

Namun dengan menggunakan batasan untuk bisa dimasukkan bekerja adalah 35 jam per minggu, sebagaimana banyak digunakan negara maju, maka tampak bahwa tingkat penganggur (atau mungkinlebih tetap setengahmenganggur) secara absolut semakin meningkat, namun secara proporsional semakin menurun. Pada tahun 2000 nanti, menurut definisi ini ada 30,84 juta penganggur di Indonesia 
dan meningkat menjadi 37,02 juta tahun 2010. Proyeksi meningkatnya secara absolut jumlah penganggur ini dapat difahami. Bahkan bisa jadi angkanya akan lebih besar lagi. Ini mengingat dalam era liberalisasi nanti bukan saja barang yang bisa bebas berlalu-lalang, melainkan juga jasa, yang di dalamnya termasuk sumberdaya manusia. Apabilatenagakerja kitayangkualitasnya relatif rendah, bersaing dengan tenaga kerja asing yang menawarkan diri di Indonesiadengan kualitas lebih baik, maka dapat diduga tenaga kerja Indonesia akan tersingkir. Sehingga bukan mustahil kekhawatiran akan terserapnya tenaga kerja Indoensia pada level pekerja bawah (blue collar workers)akan menjadi kenyataan. Atau, sangat mungkin arus tenaga kerja level bawahh ini akan terus mengalir ke luar negeri, menjadiburuh atau pembantu rumah tangga di negara lain. Ini jika persoalan tenaga kerja, terutama berkaitan dengan peningkatankualitasnya, tidaksecaralebih cepat ditangani.

\section{Masalah Ekspor}

Dalam kaitan dengan liberalisasi perdagangan, maka yang akanterjaditidak saja semakin luasnya potensi pasar yang bisa dimasuki oleh Indonesia, dan juga terbuka luasnya pasar Indonesia bagi produsen dari negara lain. Dengan demikian, dalam hal ini kembali persoalannya adalah berkaitan dengan daya saing, yakni sejauh mana produk Indonesia bisaberkompetisidenganproduk negara lain, baik di pasardomestikmaupun pasar global. Namun kecenderungan yang terjadi saat ini adalah kondisi yang tidak diharapkan, yakni semakin tersendatnya laju barang ekspor Indonesia dan meningkatnya laju porsi impor. Akibatnya, surplus neraca perdagangan Indonesia (migas dan nonmigas) semakin kecil. Namun bila dilihat lebih mikro lagi dari struktur neraca perdagangan tersebut, maka yang terjadi adalah meningkatnya defisit neraca perdagangan non migas.
Sementaraitu, jika dimasukan pula eksporimpor barang dan jasa, maka yang terjadi adalah membengkakknya defisit transaksi berjalan (current account). Data terakhir menunjukkan dalam tahun kedua Repelita VI ini defisit current account tersebut telah mencapai US $\$ 6,9$ milyar. Dilihat dari rasionya atas PDB, perkembangan selama tiga tahun terakhir defisit transaksiberjalan kian besar pula. Pada tahun 1994/1995 defisit transaksi berjalan masih $2 \%$ dari PDB, dan inimeningkat menjadi $3,3 \%$ pada tahun 1995/1996, yang kemudian diperkirakan meningkat lagi menjadi $4 \%$ dari PDB Indonesia (Kompas, 28/11/1996).

Dalam tahun 1995 ekspor total Indonesia hanya meningkat $13,39 \%$ dibandingkan tahun 1994, yakni naik dari US $\$ 40,053$ milyar menjadi US $\$ 45,418$ milyar. Sedangkan impor meningkat dua kali lebih cepat dari ekspor, yakni naik $27,03 \%$ atau meningkat dari US $\$ 31,983$ milyar menjadi US\$ 40,629 milyar. Dari jumlah eksportahun 1995 tersebut, produk migas masih memberikan kontribusi sebanyak 23,1 persen. Inimenggambarkan bahwa kontribusi komoditi minyak dan gas bumi dalam struktur ekspor masih cukup besar dan signifikan. Dengan demikian, goncangan pasaryang setiap saatmungkin terjadi pada harga migas ini, akan sangat berpengaruh pada neraca pembayaran Indonesia, khususnya neraca perdagangannya. Lebih dari itu, sampai sekarang jenis komoditi ekspor non migas tidakterlalu beragam, sehinggagoncangan pada satu jenis komoditi ekspor bisa mengganggu keseimbangan pada neraca perdagangan nasional (Tabel. 5)

Dari data pada Tabel 5 di atas, komoditi tekstil merupakan komoditi yang paling besar kontribusinya dalam ekspor Indonesia. Namun demikian perlu dicatat bahwa ekspor komoditi andalan tersebut saat ini perkembangannya tidak sepesat yang diharapkan. Bahkan peemerintah telah terpaksa merevisi target ekspor tekstil dan produk tekstil ini. Hal ini terjadi karena nnilai ekspor tekstil dan produk tesktil (TPT) 
Tabel 5 : Ekspor 10 Besar Komoditas Andalan Januari Juli 1995 dan Januari Juli 1996 (dalam ribu dollar AS)

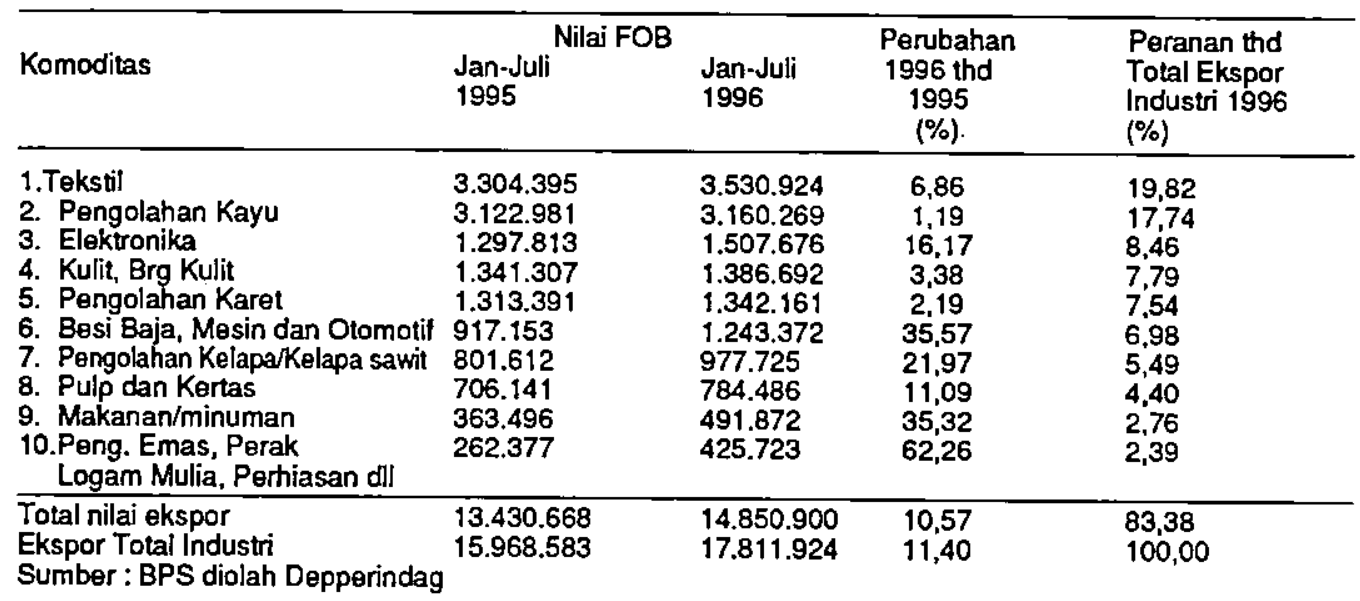

Indonesia sejak 1993 terus mengalami perlambatan, bahkan menurun. Target pertumbuhan ekspor yang ditetapkan ratarata $15 \%$ per tahun selama Pelita Vi, diperkirakan sulit mewujud. Data pertumbuhan ekspor TPT tahun 1993-1995 menunjukkan masing-masing hanya naik $1,8 \%$, turun $6,8 \%$ dan meningkat lagi menjadi $7,2 \%$. Dilihat dari nilainya, tampak bahwa ekspor tahun 1993 yang mencapai US $\$ 6,050$ milyar masih lebih besar dari ekspor 1995 yang cuma US $\$ 6,040$ milyar. Dengan perkembangan angka-angka ini maka wajar jika kemudian pemerintah merevisi target nilai ekspor komoditi yang saat ini merupakan penyumbang devisa terbesar dari nonmigas tersebut, yang semula diharapkan pada akhir Pelita VI mencapai US\$ 12 milyar, direvisi menjadi "hanya" Rp 10 milyar. Bahkan kalangan industri TPT sendiri lebih pesimis lagi, sehingga memperkirakan kemampuan ekspor TPT tersebut hanya akan mencapai sekitar US\$ 8 milyar.

Di tengah situasi merosotnya laju ekspor nonmigas tersebut, produk andalan ekspor indonesia tersebut acapkali dituduh melakukan praktek dumping. Komoditias sepetri tekstil, sepatu, sepeda, misalnya kini terus dalam penyelidikan Masyarakat Eropa karena adanya tuduhan dumping tersebut. Bahkan jika sebelumnya baru sekedar tuduhan, kini untuk komoditi tekstil tahapnya sudah pada pengenaan sangsi, yang berarti produk tersebut dikenai pajak masuk tambahan oleh negara pengimpor yang menuduh dumping tersebut. Mulai 21 November 1996 ini, ekspor kain belaco (cotton grey) ke negara anggota Uni Eropa dikenakan BMT (bea masuk tambahan) yang berkisar antara $5,2 \%$ hingga $18,3 \%$.

Sementara itu tuduhan dumping agaknya akan mengancam pula ekspor sebagian sepatu ke Uni Eropa tersebut. Menurut Ketua Asprindo (Asosiasi Persepatuan Indonesia), jika tuduhan dumping tersebut terbukti, maka BMT yang dikenakan bisa mencapai $50 \%$. Akibatnya, potensi keuntungan yang hilang - jika ini terbukti — bisa mencapai US\$ 1,2 milyar atau sekitar 2,76 trilyun. Adanya sangsi dan tuduhan dumping dari Uni Eropa ini mempunyai akibat negatif yang tidak kecil bagi perkembangan ekspor Indonesia. Ini mengingat bahwa pasar Uni Eropa merupakan pasar paling potensial untuk 
produk TPT (tekstil dan produk tekstil) dan alaskaki (footwear) bagi Indonesia. Misalnya untuk untuk sepatu, sekitar $40 \%$ pemasarannya ditujukan ke Uni Eropa. Untuk masuk ke pasar Uni Eropa tersebut, tanpa BMT (provisional duty) pun sebenarnya tidak mudah bagi Indonesia untuk bersaing dengan negara produsen lainnya. Karenanya, dapat dibayangkan bahwa dengan adanya BMT ini akan semakin sulit pula ekspor produk-produk andalan tersebut ke salah satu pasar utamanya. Daya saingnya yang menurun akibat BMT tersebut, akan semakin mempersempit pasar produk tersebut, yang berarti hilangnya sebagian pasar Indonesia. Ini mengingat tingkat kompetisi komoditi tekstil dan alas kaki di dunia yang semakin ketat.

Beberapa ilustrasi dari kasus tekstil di atas sekedar untuk menunjukkan bahwa masa depan ekspor kita akan banyak menghadapi tantangan-tantangan dalam memasuki pasar dunia, walaupun negara lain sudah membuka luas pasarnya bagi produk Indonesia. Ini berkaitan dengan ketatnya persaingan di pasar dunia tersebut, dan adanya ketentuan-ketentuan global yang tidak jarang sulit dipenuhi Indonesia. Misalnya saja kendati tarif bea masuk sudah dihapuskan, banyak negara maju yang menjadi pasar potensial Indonesia mengaitkan impornya dengan hak asasi manusia, hak buruh, ataupun dengan aspek lingkungan hidup. Oleh karena itu, menghadapi perkembangan ekonomi dunia yang semakin cepat perubahannya dan semakin ketat persaingannya, dibutuhkan pula suatu respon yang cepat, dan sikap untuk menyesuikan kebijakan dengan tuntutan yang senafas dengan persaingan bebas dan efisiensi tersebut.

\section{Penutup}

Demikianlah beberapa catatan yang berkaitan dengan problematik dan tantangan ekonomi Indonesia memasuki abad ke-21, yang akan diwaranai dengan keterbukaan ekonomi dunia yang semakin tinggi tersebut. Persaingan yang akan semakin ketat di pasar domestik dan dunia, akan berdampak sanat merugikan jika antisipasi Indonesia terlambat, dan kebijakan-kebijakan yang ada tidak menyesuaikan dengan kecenderungan tersebut. Namun demikian, ini tidak beranti bahwa globalisasi atau keterbukaan ekonomi itu pasti merugikan ekonomi Indoensia. Adanya kompetisi ini justru akan memaksa pelaku ekonomi kita untuk mencari bentuk-bentuk atau pola produksi yang efisien. Dengan kata lain, alokasi sumberdaya yang terbatas ini dapat. dilakukan lebih baik, dan lebih banyak menghasilkan barang dan jasa yang dibutuhkan umat manusia.

Jadi dasar pikiran yang demikian dilandasi oleh adanya reaksi atau respons dari para pelaku ekonomi untuk mengikuti gerak globalisasi dengan pencarian polapola produksi yang lebih efisien. Seandainya respons tersebut sangat terbatas, maka sulit mewujudkan terjadinya proses pola produksi (termasuk pemasarannya) yang semakin efisien .. Hal seperti inilah yang tampaknya terjadi di tanah air. Artinya, respons para pelaku ekonomi masih sangat lamban dalam mempersiapkan diri menuju persaingan bebas tingkat dunia ini. Bahkan beberapa sektor produksi, di tingkat lokal pun masih mendapatkan perlindungan, untuk tidak secara bebas bersaing dengan pelaku ekonomi domestik lainnya. Jika hal seperti ini masih terus terjadi, dampaknya akan membuat dayasaing ekonomi Indonesia sangat rendah dan merugikan kepentingan ekonomi nasional dalam jangka panjang.

\section{Daftar Pustaka}

Biro Pusat Statistik, Statistik Indonesia 1994, Biro Pusat Statistik, Jakarta, 1995

Edy Suandi Hamid, "Transformasi Struktural Pembangunan Ekonomi Indonesia", Kajian Bisnis, STIE 
Widya Wiwaha, Yogyakarta, 1995

Edy Suandi Hamid, " Revisi Ekspor atau Kebijakan?," Republika, Jakarta, 1 Oktober 1996

Finger, Michale, "Dumping and Anti Dumping: The Rethoric and the Reality of Protecyion in Industrial Countries", The World Bank Research Observer, vol. 7, Juli 1992, World Bank, Washington DC, 1992

INDEF, Prospek Ekonomi Indonesia 1997, Istitute for Development of Eco- nomics and Finance (INDEF), Jakarta, Oktober 1996

KOMPAS, beberapa edisi, 1996.

Pangestu, Mari dan Iwan Jaya Aziz, "Survey of Recent Development" dalam ,Bulletin of Economic Studies Vol. 30, No. 2 Agustus 1994, Canberra, ANU, 1994

Republik Indonesia, Nota Keuangan dan RAPBN 1996/1997, Republik Indonesia, Jakarta, 1996 